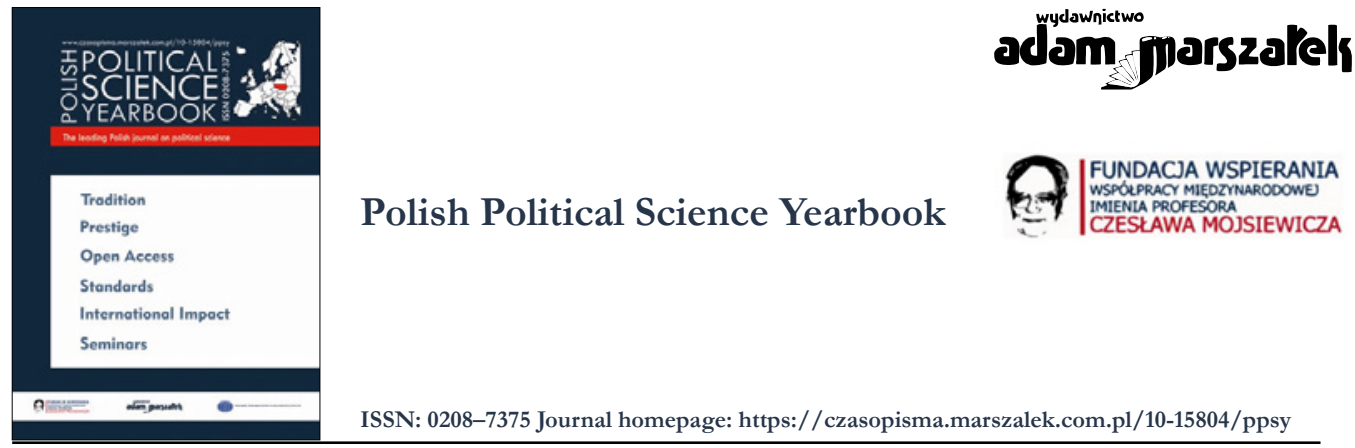

\title{
The Impact of Conflicts on Natural Resources - The Case of Sudanese Darfur Region
}

\author{
Nagmeldin Karamalla-Gaiballa ${ }^{1}$, Siham El-Kafafi ${ }^{2}$ \\ ORCID: 0000-0002-4231-80711, 0000-0002-5480-451X²
}

To cite this article please include the following information:

- Journal title: Polish Political Science Yearbook

- Volume number: 50

- Year of publication: 2021

- Published ahead-of-print

Example styles:

[APA Style]: Karamalla-Gaiballa, N., El-Kafafi, S. (2021). The Impact of Conflicts on Natural Resources - The Case of Sudanese Darfur Region. Polish Political Science Yearbook, 50 (issue number), pages. https://doi.org/10.15804/ppsy202144

[Chicago Style]: Nagmeldin Karamalla-Gaiballa, Siham El-Kafafi, “The Impact of Conflicts on Natural Resources - The Case of Sudanese Darfur Region” Polish Political Science Yearbook 50, no. [issue number] (2021).

To link to this article: https://doi.org/10.15804/ppsy202144

Published ahead-of-print

Final submission: 13 August 2021

Published online: 25 September 2021

Printed issue: 2021

Submit your article to PPSY 


\title{
Nagmeldin Karamalla-Gaiballa
}

University of Commerce and Services (Poland)

ORCID: 0000-0001-7613-3334

e-mail: (karamalla@gmail.com)

\section{Siham El-Kafafi}

Arrows Research Consultancy (New Zealand)

ORCID: 0000-0002-5480-451X

\section{The Impact of Conflicts on Natural Resources - The Case of Sudanese Darfur Region}

\begin{abstract}
This research paper explores the impact of sociological perspectives on the relationship between natural resources and conflicts. From these theoretical perspectives, many fundamental sources of conflict over natural resources are identified and defined. This research takes the approach of a case study in which the researchers investigate and analyze the sources of conflict happening in the Darfur region of Sudan. This case study explores the demographic changes, economic development, and social inequality among some factors contributing to conflict over resources in this region. The research findings demonstrated that various factors play a vital role in the availability of natural resources, which is the main reason sides other reasons flaring conflict in the Darfur region in Sudan. These factors are related to climate change, destruction of ecosystems, immigration, demographic change, and political changes. Even though various factors could impact the conflict of resources in the Darfur region in Sudan, these researchers focused in this research paper on the sociological perspective only.
\end{abstract}

Keywords: economic development, conflict, natural resources, demographic change, social inequality, Darfur

\section{Introduction}

Conflicts over natural resources are likely to occur in various contexts, from local disputes over a shared water hole to international disputes over clean air regulations. Over the past two centuries, Social Science theories provided insight and explanation regarding social, 
political, and economic factors that can be used to understand and predict the contexts in which conflict over natural resources is likely to occur.

This research paper aims to investigate and analyze the important social scientific literature on natural resource conflict illustrated through the Darfur Region in Sudan. It further provides a detailed discussion of relevant concepts and their definitions and dimensions. Building from the theories of classical and contemporary academics, an analysis of the sources of conflict is presented to assist researchers and policymakers in understanding the issues impacting natural resources and how to resolve them.

\section{Research Design and Data Collection}

The case study method is utilized in this research as the researchers agree with Baxter et al. (2008) that it facilitates the exploration of a real issue (i.e., conflict over natural resources) within a defined context (i.e., Darfur Region in Sudan) using a variety of data sources (i.e., literature review, observations and secondary research documents, e.g., governmental documentations).

The data for this research was conducted during the years 1956 to 2011 via using the following data collection methods: secondary resources documents and field observations, interviewing of governmental officials. It is due to the importance of the two dates in Sudanese political history. The first date in the history of Sudan's independence from the British throne, and the second is the independence of South Sudan from the Republic of Sudan. During that era also, wars continued in the Darfur region and did not end yet definitively.

\section{Causes of Conflict}

Paul Collier and Ane Hoeffler (2006) determined that the causes of conflicts and economic motives attract increasing attention as the most common factors that trigger and increase the risk of war. They further claimed the dependence of civil wars on the structures and organization of the rebellion. Both scholars stated that during revolutions, local people supported by ethnic leaders plunder natural resources.

Data collected from wars of 1960-1999 demonstrates that economic, political, and ethnic inequality appears as the leading explanation for the genesis of most civil wars. On the other hand, religious differences are generally a poor explanation for the causes of civil wars. In addition, it can be seen that the higher the income of a country or region, the lower the risk of civil war. Accordingly, due to the high costs associated with the conflict, the greater the risk of conflict is linked to the natural resources of the region (Collier \& Sambanis, 2006; Hoeffler, 2012).

Similarly, James Fearon and David Laitin (2003) conducted research that analyzed 127 civil wars, primarily in sub-Saharan Africa and Asia. They confirmed that regardless of how 
ethnically heterogeneous a country is, the likelihood of a civil war decreases as the wealth of the country increases. In countries where there is no visible increase in income, there is a serious risk of conflict.

In 2002, Ahmed Ali and Ibrahim Elbadawi et al. (2005) identified 17 economic, political, ethnic-religious-cultural, and external factors as causes of conflict. Based on the analysis of the wars from 1960-1999, Elbadawi and Sambanis (2002) stated that the war conflicts in Africa are primarily due to ethnic and linguistic fragmentation and high poverty, not political or economic institutions dependent on natural resources. Similarly, Frances Stewart (2010) noticed that inequality is an important element of well-being and may have detrimental consequences for further development.

\section{Social Science Theories on Natural Resource Conflict}

Several traditional theories relate social and economic factors as sources of conflicts over natural resources. Traditional Malthusian theory suggests that human consumption needs will eventually exceed the availability of natural resources (particularly food) due to population growth, causing a myriad of negative social outcomes like war, disease, and famine (Simon \& Malthus, 2018).

Classical economic theories on society and natural resources have emphasized the creation of markets as the key to balancing positive development and over-consumption. Theories in the Marxist tradition have emphasized the conflicts of interest between groups with more or less control and ownership of natural resources. The causal factors extracted from those theories include demographic change, economic development, natural resource scarcity, social inequality, social adaptability, and social breakdown. All of these factors may cause natural resource conflict (Kneese, 1988).

\section{The Case of Sudanese Darfur Region - Conflict and Natural Resources}

This section will be exploring the factors contributing to conflicts in the Sudanese region of Darfur and its impact on its natural resources. It will be conducted against the theoretical theories and how it helps predict the likelihood of either conflict or cooperation among societies and their natural resources. The following are the three driving factors impacting natural resources in the Sudanese region of Darfur: demographic change, economic development, and social inequality.

\section{Demographic Change}

Alex de Sherbinen (1995) established that particular kinds of population changes are associated with political instability, which leads to conflict over natural resources. It has been demonstrated through historical conflicts in China, Latin America, and Europe over rural 
lands between farmers and landlords. Thayer (2009) reiterated in his study that international politics should emphasize the importance of pollution (i.e., demographic changes) as it plays a great role in conflict studies.

About the Case of the Sudanese Darfur Region, demographic change is expected to indirectly affect natural resource conflict as it influences economic development, natural resource scarcity, and social inequality. The population of the North Darfur Region has increased since 1973 from 530,000 to 1.15 million in 1993. According to the last census in 2009 , this figure was already about 2.1 million people. It means that the population has increased almost four times over the past thirty years. For example, the population of Kabkabiya increased from 89,000 to 270,000 in the period 1973-2003, and the population density increased from $8 / \mathrm{km} 2$ to $23 / \mathrm{km} 2$ at the same time. These numbers show that the population increased threefold during this period. On the other hand, arable land in Darfur totaled 760 thousand hectares in 1961 and increased until 2002 only in the North Darfur region to 2.5 million (Schimmer, 2008).

This increase in population occurred due to the conversion of agricultural land into pastures, thus increasing friction between shepherds and farmers. In addition, soil cultivation in arid regions with insufficient rainfall led to soil erosion, which increased the environmental degradation process and caused low yields. The drop in land productivity pressured the farmers to look for opportunities to expand their farms to obtain the crops needed to feed more people (Bushra \& Taha, 2000).

Furthermore, there has been an increase in animals from 3.7 million heads in 1976 to 13 million heads in 2002. It means that the number of farmed animals has more than tripled in 26 years. From this, it can be concluded that there is an increasing number of people and animals, and therefore competition for rare resources is intensified, leading to an increase in conflict of interest over resources in the region between shepherds and farmers (Bushra \& Taha, 2000).

Due to the increase in the population and animal population, farmers began to expand their cultivation area more often and use field residues and allocate them for either feeding their animals or for sale, which also hurt the shepherds. The concentration of nomad animals in dry areas has increased livestock mortality due to a lack of access to both feed and water. In the long run, animals were increasingly plundered and sold on trade routes, becoming increasingly less secure. Conflicts usually start locally and only then turn into general tribal or ethnic disputes, which ultimately escalate to a serious regional political conflict when government-backed armed groups join the fight (Laki, 1994).

Also, there is a need to give attention to the role played by the other neighboring countries to Sudan, i.e., Chad and the Central African Republic, which had lots of conflicts, and their refugees ran to Sudan and settled in Darfur Region. Apart from the natural geographical proximity of the region, the refugee's decision was influenced by family connections and common language among the tribes on both sides of the border. Another important factor was the shared history of the Bilad as-Sudan belt stretching from Senegal 
and Gambia in the west to Ethiopia in the east across the entire African continent (Otte \& Chilonda, 2002).

Events in neighboring Chad show us overlapping ecological and political crises. It is estimated that since $1973,70 \%$ of cattle in Chad have died or been previously slaughtered. Baggara tribes from the province of Uadaju in Chad fell into terrible poverty, which strengthened their sense of harm and their desire to retaliate. Thousands of nomads Baggara and Tubu deprived of food fled from Chad to Sudan Darfur Region and further east, toward the Nile, searching for water, food, and work. In contrast, the prouder sons of the warlike Gourane tribes, Zaghawa Bedeyat, resorted to banditry due to difficult times. As a result, during the drought years in the Sahel, there were few safe areas on the border between Chad and Sudan for merchants and pilgrims, and even for soldiers (Otte \& Chilonda, 2002).

In 1973, due to the civil war in Chad, an influx of Chadian refugees (approximately 200,000 ) moved to West Darfur Region, escaping drought. By 2004, the region's population had increased to around 6.5 million due to the influx of refugees from Chad. It is estimated that at least $10 \%$ of Chad's population lived in Sudan at the time. It is difficult to estimate the real number because "refugees" arrived individually and in family groups. Individuals with relatives on the other side of the border blended into the Darfur Region community imperceptibly. In the absence of a stronger national identity (in the sense of nationality), it was not a problem for them to transfer loyalty from the leaders of groups from Chad to the leaders of Sudan-related tribes. It also enabled joining paramilitary forces, such as the Popular Defense Forces, which facilitated the acquisition of Sudanese citizenship. It allowed the Sudanese authorities to estimate the number of young people who arrived from Chad - the main source of recruits for tribal militias emerging in the Darfur Region (Behrends, 2008).

In the seventies, Darfur for Chad became what the Democratic Republic of Congo did for Rwanda - a place of refuge for the opposition, which also received logistical support from the Sudanese authorities. Regardless of the direction of American policy towards Libya and its policy regarding Chad and Sudan, each side tried to create armed troops. Internal conflicts in Chad that have existed since the early 1970s and the fighting that has continued in South Sudan for the past two decades have resulted in easy access to various weapons. The problem deepened over time when the use of modern weapons by various types of gangs began. It became a huge problem and required firmness from the state authorities responsible for tracking down the perpetrators and bringing them to justice (Manger, 2006).

There were constant conflicts between gangs of armed refugees and settled farmers. Fur farmers, practicing burning the remains of fields, forced Arab shepherds to move to other areas, thus limiting their access to water sources. The Fur militia was formed, which called itself the Darfur Federal Army. In May 1988, it had about six thousand armed police officers. Their training centers were located in southwestern Darfur, most in the western part of Bahr al-Ghazal and on the border with the Central African Republic. In defense 
against farmers, the nomads formed the "Arab Association", which in Darfur became the basis for the development of Arab nationalism. This new ideology articulated the needs of Arab tribes and called for unity to defend common interests and use new defensive methods in the fight against the enemy. This movement among Arab tribes, supported by ideology, emphasized Arab migration in the region and called for the mobilization of Arab nomads to gain independence in Chad (Jok, 2001).

\section{Economic Development}

Economic development in the Darfur region is predicted to have a direct positive effect on population growth and urbanization and a negative effect on natural resource conflict directly and indirectly through social adaptability. The Darfur region has been neglected by a lack of sufficient care and attention from successive governments and poor infrastructure, transport, and road development. Additionally, Darfur Region has been harmed due to a lack of education and a health system (Young \& Osman, 2006).

Previous governments neglected economic development and did not introduce a federal system in the Darfur Region, especially under military rule. These factors were exacerbated by the environmental crisis, drought, and desertification, which led to the emergence of a resistance movement that called for a fight against the central government. Groups such as the Justice and Equality Movement or the Sudan Liberation Army rose in Darfur Region, which spread to other regions. Both groups within the resistance movement strove to achieve a fairer distribution of budget funds and a greater interest in the Khartoum and Darfur Region. Thus, the struggle between the Darfur Region opposition and the Sudanese Government led to the Darfur Region's significant success (Young \& Osman, 2006).

It was difficult to initiate development in the Darfur Region due to the lack of a reliable and clear development program. After the Sudanese Government failed to solve the problem with the resistance movement in the region, the government sought to exploit the conflict over natural resources to achieve its own political goals and subjugate the region and its resources, in particular the future extraction of natural resources, and at the same time weaken the resistance movement. To achieve these goals, the Government in Khartoum has set up militias of Janjawid, armed gangs, originally Chad refugees specialized in robbery and theft. They arose from armed groups of Arab origin operating outside the law. These troops used the weapons that the Government in Khartoum supplied them. They set fire to murder and robbery in villages, among resistance farming or craft tribes, mostly Native African tribes such as the Fur. These actions led to a humanitarian disaster in Sudan unprecedented in modern history (Musa, 2019b). 


\section{Social Inequality}

Social inequality in the Darfur Region is predicted to have both negative direct and indirect effects on natural resource scarcity and related conflict. The armed conflict in Darfur between ethnic groups is often perceived as "racial". We can see a two-stage course and distinguish two main currents. The first is a typical "tribal" conflict, manifested in occasional clashes that were characteristic of the 1950s and continued until the 1970s. The second trend of conflicts included deeper, broader, more modern disputes. They appeared in the mid-eighties. While conflicts that arose in the past easily found satisfactory solutions, the next chapter in the history of conflicts turned out to be more complex since difficulties arose in resolving these conflicts by traditional methods that boiled down to financial compensation. Clashes occurring since the mid-eighties, caused by competition for water and pastures, began to widen until their character took on the features of a full-scale war in 2003. Tens of thousands of people lost their lives, entire villages ceased to exist, many were burned, people lost their property, and a huge number of people were forced to resettle (Daly, 2010).

Successive governments pursued a whole range of strategies to resolve various conflicts, but their efforts proved ineffective, and in many cases, even accusations of central government bias and unequal treatment of the parties to the conflict arose. Disputes occurring before the mid-eighties are characterized by low sharpness and local character. Two ethnic groups rarely disputed them. Examples of such conflicts are disputes that took place between Zaghawa and Almhiria in 1968 and between Almaalaa and Rizeigat in the same year, as well as between Rizeigat and Misseriya from 1972 to 1974, and Beni Halba and Almhiria from 1975 to 1977, and between Altaihh and Salamat from 1978 to 1981 (Chalk \& Kelton, 2009).

The conflict in Darfur Region began in the mid-1980s. It was known as the wartime uprising of Arab tribes. In 1984, during the drought, the war swept the entire region. The main hotspot that led to the explosion was the collapse of existing economic ties between Fur farmers and shepherds from the Zaghawa group. In the past, shepherds were allowed to enter the Jabal Marra zone with herds and graze livestock on farmland residues in December and January, when other pastures were still inefficient. Nomads could stay there until the beginning of the rainy season, which began in April and May. Farmers allowed them because, firstly, they received some of the animals from shepherds, and secondly, animal residues and waste assisted fertilization (Faris, 2007).

Conflicts between 1987-1989 calmed down when the democratic Government in Khartoum was overthrown, and the Islamic leaders stopped fighting in the Darfur Region. This simple fact should remind us that the conflict in Darfur began as a civil war of which the government was not part. Nevertheless, in 1989, the government was part of the conflict after taking over the situation and promised to resolve the crisis (Flint, 2010)

Both representatives of Fur and Arabs came to an agreement in less than a week with the opponents and signed a peace protocol declaring a return to the situation before the attack. 
However, their initiative failed in the long run, and the war broke out on an even larger scale. When the government became part of the conflict, it lost its position as a mediator. As a result, the local conflict in Darfur Region developed into a regional conflict when it became interested in the neighboring countries of Sudan (i.e., Chad, Libya, Eritrea). Accordingly, it was internationalized by joining with financial, material, and military assistance from countries outside the region (i.e., China, Russia, USA). Hence it is classified as an internationalized internal conflict (Flint, 2010).

In 2002-2003, a fight broke when anti-government forces in Darfur Region started active cooperation with the opposition in the center of the country. Since then, the local conflict has started to turn into a national conflict. In 2003, unlike 1987-1989, the conflict spread over all of Sudan, and the problem was not just Darfur Region. From the point of view of Arab tribes, the problem began when Fur farmers began to proclaim their right to land belonging to Arab tribes. When they began to define themselves according to colonial (Western) terminology as "Africans" who are threatened by "Arabs", in a country where such divisions were unknown and where all groups were referred to by their ethnic or tribal name. Fur, in turn, considered themselves victims of Arab political domination, resulting in racism. They signed the content of a letter from 27 tribes to Prime Minister Sadiq al-Mahdi, in which his authors calling themselves the "Arab Association" ask him for support in the conflict (Willams \& Bellamy, 2005).

This 2003 war, through its brutality, lack of inhibitions, and restrictions, has finally acquired racist traits. Hordes of Janjaweed attacked the villages of Fur, killing everyone without exception, appropriating farmers' property and land. Fur also began to organize their militia, responding similarly. After the fighting lasting from 1987 to 1989, both sides finally met in Al-Fashir at a regional authorities' conference from May 9 to July 8, 1989. It revealed mutual hostility. The Arabs claimed that Fur started the entire conflict, trying to expand the so-called "Negra belt" (al-hizam Zandji), aiming to exclude Arabs, who as equal citizens have the right to access natural resources, especially during the crisis. The position of the Arab Association was expressed by the secretary of their delegation, saying: "Our tribes and the Fur tribe once coexisted peacefully" (Musa, 2019a).

The destabilization situation arose in the late 1970s when Fur began to proclaim the slogan that "Darfur is only for Fur". It coincided with Darfur's first regional government was led by people from Fur who did nothing to change the situation. Arabs were portrayed as foreigners who should be evicted from Darfur. The militia created by Fur was trained under the supervision of Governor Darfur. Therefore, our need for self-defense is justified, and we will defend our right to access water and pastures. It was Fur who started this war in the pursuit of extending Zandjis al-hizam, wanting to remove all Arabs from the area. "In turn, representatives of Fur pointed out that the purpose of the Arab Association was to expand the "Arab belt" (al-hizam al-Arabi) and the destruction of the population of Fur. The secretary of their delegation even stated that it was: "A dirty war that resulted from 
the economic war aimed at genocide and the partition of our homeland to achieve certain political goals" (Dagne, 2012).

In a situation where each party only defended its case, their arguments began to take on a racist tone. Both saw themselves as victims. On one side stood camel shepherds from northern Darfur and landless refugees from Chad residing in Darfur, who saw their protectors in strong Arab leaders, as in Colonel Gaddafi and the Islamic Government in Khartoum. On the other hand, there were groups settled in Darfur and non-Arab forces in Chad under Hissen Habre and Western allies such as France, Israel, and the US. The polarization of opposing narratives fed increasing tension. In May 1989, the conflict spread beyond the lands around Jabal Marra (Behrends, 2007).

For the first time, almost all Darfur pastoral tribes, Arab and non-Arab, gathered under a common banner, with Libyan support behind them. The traditional conflict resolution system was completely broken down when both sides openly disregarded the old conventions. In particular, the boycott of Baggar's chief conference in Al-Fashir was against practice. Governor of Darfur, Dr. Eltigani Ateem, pointed out that mass crimes committed by both parties meant that the conflict is now a completely new character. In his opinion, he was imposed on Darfurians by external forces (Flint, 2010).

The combination of drought, an unsuccessful attempt to reform the colonial system, and the influx of weapons brought about a series of wars, more catastrophic than any other regional conflicts in history. Fighting resumed within a few days with extraordinary cruelty. More than 50,000 people from the Fur people sought refuge in Nyala. The Sudanese Government only regretted the above situation in Darfur and criticized the influence of foreign forces in this conflict. The change occurred suddenly on June 30,1989, when previously unknown officers under the command of General Hasan Ahmad al-Bashir overthrew the civil Government of Prime Minister Sadiq al-Mahdi. The al-Bashir Government sought to stabilize the situation by reforming the existing system without questioning its basic provisions, which only restored peace for a moment (Collins, 2006).

\section{Research Findings}

The following are the research findings:

- Natural resources have more than one user in Darfur. Without clear agreements and, this opens doors for conflicts, which reflect the power relations between users. The evidence for this is the failure of all the agreements signed so far between the warring parties to stop the fighting in Darfur, such as the first and second Abuja Agreements under the auspices of the United Nations, as well as the Doha Agreement for Peace in Darfur. Because they simply did not respect with precision and sufficient justice the sovereignty of the peoples in the region over their natural wealth and resources.

- Growth, combined with the destruction of ecosystems in Darfur, leads to a situation where competition over resources increases. Indeed, ecological degradation resulting 
from nomadic movements, excessive grazing, and competition for natural resources has been the cause of subsequent conflicts and disputes between nomads and farmers. Still, the idea that these factors were the main causes of the current Darfur conflict is untrue. Explaining the current conflict in terms of competition for natural resources and ethnicity reduces the importance of political and socio-economic problems of the country and weakens the ability to address the most important causes of conflict.

- Climate change substantially affects the Darfur region, and longer drought periods increase the pressure on natural resources, thus triggering new or worsening existing conflicts.

- Political changes in many countries, especially in fragile contexts, can create new aspirations for exploiting resources. Functioning institutions, arrangements, and regulations are especially necessary for such situations.

- Official laws regarding natural resources management often do not match traditional indigenous user rights and regulations, thus causing conflicts between government officials and local users. For example, in Darfur, the ownership of lands and their expropriation is subject to local laws inherited from the time of the sultans who ruled the region, and therefore any attempt to change these laws may lead to the outbreak of more conflicts

\section{Conclusion}

This research paper explored the impact of conflict on natural resources in general and, more specifically, on the case of the Sudanese Darfur Region. The case study demonstrated the three main determinants of conflicts, i.e., demographic change, economic development, and social inequality, and their role in the Darfur Region Crisis. The Darfur Region crisis results from the marginalization of the population in terms of political and economic rights in many areas and sectors. A dialogue aimed at adopting peaceful solutions is not a sufficient solution, as the causes of the conflict cannot be removed in this way. Political action is needed to remove the real roots of the conflict.

The armed conflict in Darfur Region can be compared to Newton's third law of motion, which states that action produces a reaction. The environmental crisis resulting from years of neglect and marginalization of the province by the central government and the subsequent inept attempts to subjugate Darfur by Khartoum was perceived by the Darfurians as a deep injustice and an attack and violation of their rights. As a result, Darfurians reacted by attempting to defend the autonomy of their region. 


\section{References}

Ali, A.A.G., Elbadawi, I.A., \& El-Batahani, A. (2005). Sudan's civil war: Why has it prevailed for so long?. Understanding Civil War: Evidence and Analysis, Volume 1: Africa, I, 193-219. e:\%5CArticle\%5CAli et al(2005-Sudan's civil war).pdf

Behrends, A. (2007). The Darfur conflict and the Chad/Sudan border: regional context and local reconfigurations. Sociologus, 57(1), 99-131.

Behrends, A. (2008). Fighting for oil when there is no oil yet: The Darfur-Chad border. Focaal, 52, 39-56.

Bushra, E.-S.E., \& Taha, M.O. (2000). A model for the distribution of waters of international rivers among sharing countries. Sudan Notes and Records, 4, 159-171.

Chalk, F., \& Kelton, D. (2009). Mass-Atrocity Crimes in Darfur and the Response of Government of Sudan Media to International Pressure. In A. Grzyb (Ed.), The World and Darfur: International Response to Crimes Against Humanity in Western Sudan (pp. 112-151). McGill-Queen's University Press. http:// www.jstor.org/stable/j.ctt8031c.11

Collier, P., \& Sambanis, N. (2006). Understanding Civil War: Evidence and Analysis: Vol. 1. Africa (pp. 43-5541-43-5541). World Bank. https://doi.org/10.5860/choice.43-5541

Collins, R.O. (2006). View of The Disaster in Darfur in Historical Perspective|Journal of Conflict Studies. University of California Santa Barbara. https://journals.lib.unb.ca/index.php/jcs/article/view/4511/5320

Dagne, T. (2012). Sudan: The crisis in Darfur and status of the north-south peace agreement. In East African Country Tensions and Relations (pp. 43-87). Nova Science Publishers, Inc.

Daly, M.W. (2010). Darfur's sorrow: The forgotten history of a humanitarian disaster second edition. In Darfur's Sorrow: The Forgotten History of a Humanitarian Disaster Second Edition. Cambridge University Press. https://doi.org/10.1017/CBO9780511761232

De Sherbinen, A. (1995). World Population Growth and US National Security, Environmental Change and Security Project Report of the Woodrow Wilson Center 1. In P.J. Simmons (Ed.), Environmental Change and Security Project (pp. 24-29).

Elbadawi, I., \& Sambanis, N. (2002). How Much War Will we see?. Journal of Conflict Resolution, 46(3), 307-334. https://doi.org/10.1177/0022002702046003001

Faris, S. (2007). The Real Roots of Darfur. The Atlantic Monthly, 299(3), 67-69.

Fearon, J.D., \& Laitin, D.D. (2003). Ethnicity, Insurgency, and Civil War. American Political Science Review, 97(01), 75-90. https://doi.org/10.1017/S0003055403000534

Flint, J. (2010). The Other War: Inter-Arab Conflict In Darfur (Small Arms Survey HSBA Working Paper.). https://www.files.ethz.ch/isn/123329/SWP_22.pdf

Hoeffler, A. (2012). Growth, Aid and Policies in Countries Recovering From War. In Centre for the Study of African Economies (Issue October). University of Oxford.

Jok, J.M. (2001). War and Slavery in Sudan. In War and Slavery in Sudan. University of Pennsylvania Press. https://doi.org/10.9783/9780812200584

Kneese, A. (1988). The Economics of Natural Resources. Population and Development Review, 14(281), 281-309. https://doi.org/10.2307/2808100

Laki, S. (1994). Desertification in the Sudan: causes, effects and policy options. International Journal of Sustainable Development \& World Ecology, 1(3), 198-205.

Manger, L. (2006). Resource conflict as a factor in the Darfur crisis in Sudan. https://www.mpl.ird.fr/ colloque_foncier/Communications/PDF/Manger.pdf

Musa, S. (2019a). Conflict in Darfur: Causes and Implications. In Hawks and Doves in Sudan's Armed 
Conflict: Al-Hakkamat Baggara Women of Darfur (pp. 30-45). Boydell and Brewer Limited. https:// doi.org/10.1017/9781787442320.004

Musa, S. (2019b). Ethnicity and Administration in Darfur. In B. and B. Limited (Ed.), Hawks and Doves in Sudan's Armed Conflict: Al-Hakkamat Baggara Women of Darfur (pp. 9-29). Boydell and Brewer Limited. https://doi.org/10.1017/9781787442320.003

Otte, M.J., \& Chilonda, P. (2002). Cattle and Small Ruminant Production Systems in Sub Saharan. Fao, 1-98. http://www.fao.org/3/a-y4176e.pdf

Schimmer, R. (2008). Tracking the Genocide in Darfur : Population Displacement as Recorded by Remote Sensing. Genocide Studies Working Paper No. 36, 36, 46.

Simon, J., \& Malthus, T.R. (2018). An Essay on the Principle of Population as it Affects the Future Improvement of Society (First Edition). In The Economics of Population (pp. 41-50). Routledge. https://doi. org/10.4324/9781351291521-6

Stewart, F. (2010). Horizontal Inequalities as a Cause for Conflict: A Review of CRISE Findings. In World Development Report 2011 Background Paper (Issue January).

Thayer, B.A. (2009). Considering population and war: A critical and neglected aspect of political studies. Philosophical Transactions of the Royal Society, 364(1532), 3081-3092. https://doi.org/10.1098/ rstb.2009.0151

Willams, P., \& Bellamy, A. (2005). The Responsibility To Protect and the Crisis in Darfur. Security Dialogue, 36(1), 27-47.

Young, H., \& Osman, A. (2006). Challenges to Peace and Recovery in Darfur. Feinstein International Center. https://www.cmi.no/file/1891-Challenges-to-Peace-and-Recovery.pdf 